\title{
A NEW ANTIBIOTIC K-82 A AND MINOR COMPONENTS, PRODUCED BY STREPTOMYCES LAVENDULAE, STRAIN NO. K-82
}

\author{
Motoo Shibata, Masaru Uyeda, Yutaka Kido, Norio Toya, \\ Ryuichi NaKashima and Ryushi Terazumi \\ Faculty of Pharmaceutical Sciences, Kumamoto University, \\ Kumamoto 862, Japan
}

(Received for publication May 27, 1980)

\begin{abstract}
From the results of taxonomic studies, Streptomyces sp. strain No. K-82 isolated from a soil sample collected in Kumamoto city, was identified as a strain belonging to Streptomyces lavendulae WAKSMAN \& HeNRICI 1948. The strain produced an active new antibiotic called K-82 A and minor components named the B complex. Antibiotic K-82 A was isolated as dark reddish needles by silica gel column chromatography and found to have both antibacterial activity and high phage induction activity. The K-82 B complex was found to consist of at least five components, among which $\mathrm{K}-82 \mathrm{~B}_{2}$ and $\mathrm{B}_{3}$ were isolated as crystals. Substance $\mathrm{K}-82 \mathrm{~B}_{2}$ was identified as benzoic acid from its physicochemical properties. Substance $\mathbf{B}_{3}$ like $\mathbf{B}_{2}$ had only marginal antibiotic activity.
\end{abstract}

In the course of our screening for new antibiotic, Streptomyces sp., strain No. K-82 was found to be highly active against Gram-positive and Gram-negative bacteria. Several active components were isolated in crystalline form and their biological and physicochemical properties were clarified. The present paper deals with the taxonomic studies of Streptomyces sp., strain No. K-82, fermentation, isolation, and physicochemical properties of the antibiotics.

\section{Materials and Methods}

\section{Mycological properties}

The organism was examined by a light microscope (L type, Nihon Kogaku K. K.) and an electron microscope (JEM-50 B, Japan Electron Optics Laboratory, Co., Ltd.) every 7 days after incubation on modified glucose asparagine agar at $28^{\circ} \mathrm{C}$. The methods and media for examination of cultural and physiological properties were made according to the recommendation of the International Streptomyces Project. ${ }^{1)} \quad$ Color determinations and examinations of carbon utilization of the culture were made according to RAYNER's description ${ }^{2)}$ and PRIDHAM's method ${ }^{3)}$, respectively.

Fermentation

Shaking culture fermentation were carried out with $50 \mathrm{ml}$ of a medium in 200-ml Erlenmeyer flasks. Spores from a slant culture were inoculated into a seed culture medium containing $5 \%$ starch, $0.5 \%$ peptone, $1 \%$ soybean flour, $1 \%$ corn steep liquor, $0.5 \% \mathrm{NaCl}$ and $0.3 \% \mathrm{CaCO}_{3}$. After incubation for 24 hours at $34^{\circ} \mathrm{C}$, the resultant culture was inoculated into the same main culture medium as described above, with the inoculum size of $4 \%$. Fermentations were carried out for 96 hours at $34^{\circ} \mathrm{C}$ on a rotary shaker. Jar fermentations were carried out for 48 hours at $34^{\circ} \mathrm{C}$ with stirring $(350 \mathrm{rpm})$ and under aeration (20 liters/min). Six hundred $\mathrm{ml}$ of the seed culture, prepared as described above, were inoculated in a 30 -liter jar-fermentor containing 14 liters of the medium.

\section{Antibiotic Assay}

(1) Antibacterial activity: The conventional serial agar dilution method and cup or paper disk method were applied in this study using Staphylococcus aureus or Sarcina lutea as a test organism. 
(2) Phage induction activity: The serial phage induction-agar dilution method ${ }^{4)}$ was applied in this study, using $E$. coli $\mathrm{K}-12 \lambda$ as a lysogenic strain. The assay medium consisted of $1 \%$ peptone, $0.2 \%$ casamino acid, $0.2 \% \mathrm{NaCl}$ and 0.6 or $1.2 \%$ agar.

Thin-layer and paper chromatography

Thin-layer plates were prepared with a Desaga applicator from silica gel G (Type 60, Merck). The detection of the antibiotic was made by bioautography on bouillon agar seeded with S. aureus.

\section{Results and Discussion}

Taxonomic Characteristics of Streptomyces sp., Strain No. K-82

The spore chains terminate in loops and in spirals with a few turns. Spores are oval with smooth surface. In general, the aerial mass color is pink to vinaceous and melanoid pigments are observed on proteinaceous media. In carbon-source utilization studies, good growth or moderate growth was observed with D-glucose, D-fructose, L-arabinose. No growth was observed with D-xylose, $i$-inositol, D-mannitol, raffinose, sucrose and rhamnose. The growth of the strain occurred between $20^{\circ}$ and $43^{\circ} \mathrm{C}$ and its optimum temperature was $37^{\circ} \mathrm{C}$. The growth and sporulation occur at pH's ranging from 5.0 to 8.0 and its optimum $\mathrm{pH}$ was 7.0 .

These properties were compared with the species descriptions in International Streptomyces Project and BergeY's Manual of Determinative Bacteriology, 8th ed. ${ }^{5)} \quad$ From the melanoid pigment formation, spore surface and spore chain morphology, the strain was identified as a strain belonging to Streptomyces lavendulae WAKSMAN \& HENRICI 1948.

\section{Production and Isolation of Antibiotic K-82 A and the K-82 B Complex}

The culture filtrate (10 liters) was adjusted to $\mathrm{pH} 2.0$ with $6 \mathrm{~N} \mathrm{HCl}$ and extracted two times with ethylacetate at one fourth volume of the filtrate. After washing and dehydration with $\mathrm{Na}_{2} \mathrm{SO}_{4}$, the extract were concentrated in vacuo and fractionated with ether into ether-soluble and ether-insoluble fractions. The insoluble fraction was dissolved in methanol and reprecipitated with ether. The precipitate was filtered off, followed by vacuum drying to give $1 \mathrm{~g}$ of crude $\mathrm{K}-82 \mathrm{~A}$ and the filtrate plus ethersoluble fractions were combined and concentrated in vacuo to give crude K-82 B. The antibiotic K-82 A was then subjected to column chromatography on silica gel. The column was eluted with solvent mixture $\mathrm{I}\left(\mathrm{CHCl}_{3}-\mathrm{MeOH}-\mathrm{AcOH}, 30: 1: 1\right)$. The active fractions were concentrated in vacuo to give a dark reddish powder of partially purified K-82 A. The partially purified K-82 A was then dissolved in a small amount of $1 \mathrm{~N}$ ammonium hydroxide and after addition of methanol, acidification with acetic acid gave dark reddish needles of purified K-82 A.

On the other hand, the crude K-82 B complex was found to contain, at least, five components by thin-layer chromatography and these were named K-82 $B_{1}, B_{2}, B_{3}, B_{4}$ and $B_{5}$ in the order of increasing Rf values. Purification of these components was also made by silica gel column chromatography. Using solvent mixture II $\left(\mathrm{C}_{6} \mathrm{H}_{6}-\mathrm{AcOEt}, 3: 1\right)$, the $\mathrm{K}-82 \mathrm{~B}_{2}$ and $\mathrm{B}_{3}$ fractions were separated from the $\mathrm{K}-82 \mathrm{~B}_{4}$ and $\mathrm{B}_{5}$ fractions. Further purifications of the former two fractions were made by silica gel column chromatography using solvent mixture III $\left(\mathrm{C}_{6} \mathrm{H}_{6}\right.$ - AcOEt, 9: 1). The active fractions were concentrated in vacuo to give light yellow oils of partially purified $\mathrm{K}-82 \mathrm{~B}_{2}$ and $\mathrm{B}_{3}$. The partially purified $\mathrm{K}-82 \mathrm{~B}_{2}$ and $\mathrm{B}_{3}$ were rechromatographed on another silica gel column. Elution with solvent mixture IV $\left(\mathrm{C}_{6} \mathrm{H}_{6}-\mathrm{Et}_{2} \mathrm{O}\right.$, 9: 1), followed by evaporation gave pure colorless prisms of $K-82 \mathrm{~B}_{2}$ and yellow needles of K-82 $\mathrm{B}_{3}$.

Crude K-82 $\mathrm{B}_{4}$ and $\mathrm{B}_{5}$ were similarly purified by column chromatography on silica gel. $\mathrm{K}-82 \mathrm{~B}_{4}$ 
and $\mathrm{B}_{6}$ were eluted with solvent mixture II and V $\left(\mathrm{C}_{6} \mathrm{H}_{6}\right.$ - AcOEt, $\left.1: 1\right)$, respectively. The $\mathrm{B}_{5}$ fraction was concentrated in vacuo and rechromatographed on active carbon column and elution with solvent mixture VI (AcOEt - $\mathrm{MeOH}, 1: 1)$ and gave a light yellow oil (K-82 $\left.\mathrm{B}_{5}\right)$.

\section{Physicochemical Properties}

Physicochemical properties of K-82 A, $\mathrm{B}_{2}$ and $\mathrm{B}_{3}$ are shown in Table 1. K-82 A gave negative Molisch, anthrone, Fehling, Benedict, ninhydrin, ferric chloride, Elson-Morgan, biuret, xanthoprotein, Pauli, SAKaguchi and EhrLich reactions. No conclusion about a molecular weight determination of K-82 A could be drawn from mass-spectrometry, although ion peaks at $\mathrm{m} / \mathrm{z} 398$ and $\mathrm{m} / \mathrm{z}$ 354 were observed in the higher mass units region. Further investigation is necessary. The ultraviolet absorption and infrared absorption spectra of K-82 A, $\mathrm{B}_{2}$ and $\mathrm{B}_{3}$ are shown in Figs. 1 and 2, and Figs. 3 and 4 , respectively. K-82 $\mathrm{B}_{2}$ was identified as benzoic acid, $\mathrm{C}_{7} \mathrm{H}_{6} \mathrm{O}_{2}$ from the elementary analysis and infrared spectrum. The Rf values of these antibiotics on TLC are given in Table 2.

Table 1. Physicochemical properties of antibiotics K-82 A, $\mathrm{B}_{2}$ and $\mathrm{B}_{3}$.

\begin{tabular}{|c|c|c|c|}
\hline & A & $\mathrm{B}_{2}$ & $\mathrm{~B}_{3}$ \\
\hline Appearance & dark reddish needle & colorless prism & yellow needle \\
\hline Melting point $\left({ }^{\circ} \mathrm{C}\right)$ & $210 \sim 230$ (dec.) & $106 \sim 109$ & $150 \sim 153$ \\
\hline$[\alpha]_{\mathrm{D}}^{25}$ & $+20($ c $0.1, \mathrm{MeOH})$ & - & - \\
\hline $\mathrm{pKa}^{\prime}$ & $6.45(\mathrm{MeOH})$ & - & - \\
\hline $\mathrm{UV} \lambda_{\max }^{\mathrm{MeOH}} \mathrm{nm}\left(\mathrm{E}_{1 \mathrm{~cm}}^{1 \%}\right)$ & $230(790)$ & $228(728)$ & $287(64.0)$ \\
\hline & $250(787.5)$ & $273(93.2)$ & \\
\hline & $280(525)$ & $300(46.8)$ & \\
\hline & $390(306 \quad)$ & & \\
\hline \multicolumn{4}{|l|}{ Elemental analysis } \\
\hline \multirow[t]{3}{*}{ Found $(\%)$} & $C: 62.65$ & C: 68.57 & $\mathrm{C}: 56.58$ \\
\hline & $\mathrm{H}: \quad 3.65$ & $\mathrm{H}: \quad 5.31$ & $\mathrm{H}: \quad 5.37$ \\
\hline & $\mathrm{N}: 11.85$ & $\mathrm{~N}: \quad 0.00$ & $\mathrm{~N}: \quad 0.00$ \\
\hline Molecular weight & - & $122^{*}$ & - \\
\hline Solubility & & & \\
\hline Soluble in & $\begin{array}{l}\text { alkaline water } \\
\text { N,N-dimethylformamide }\end{array}$ & most organic solvents & most organic solvents \\
\hline Slightly soluble in & lower alcohols & $n$-hexane & $n$-hexane \\
\hline Insoluble in & $\begin{array}{l}\text { acidic water, ether, } \\
n \text {-hexane }\end{array}$ & water & water \\
\hline
\end{tabular}

* Mass-spectrometry.

Fig. 1. UV absorption spectra of antibiotic K-82 A.

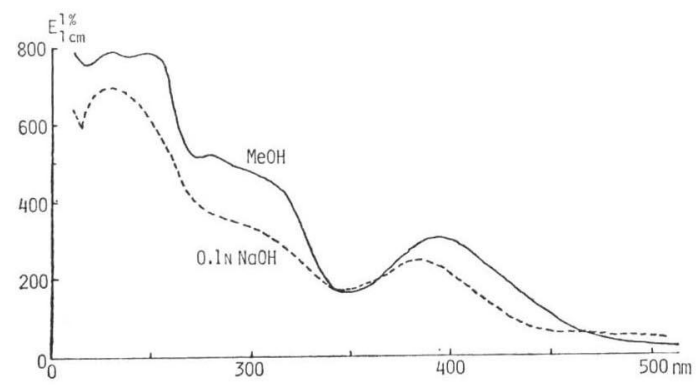

Fig. 2. UV absorption spectra of antibiotics $\mathrm{K}-82 \mathbf{B}_{2}$ and $\mathrm{B}_{3}(\mathrm{MeOH})$.

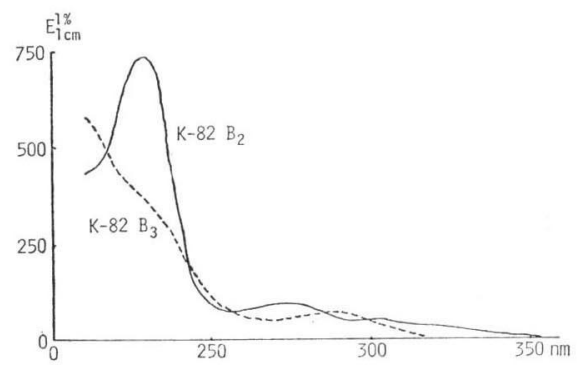


Fig. 3. Infrared absorption spectra of antibiotic K-82 A and rufochromomycin (KBr).
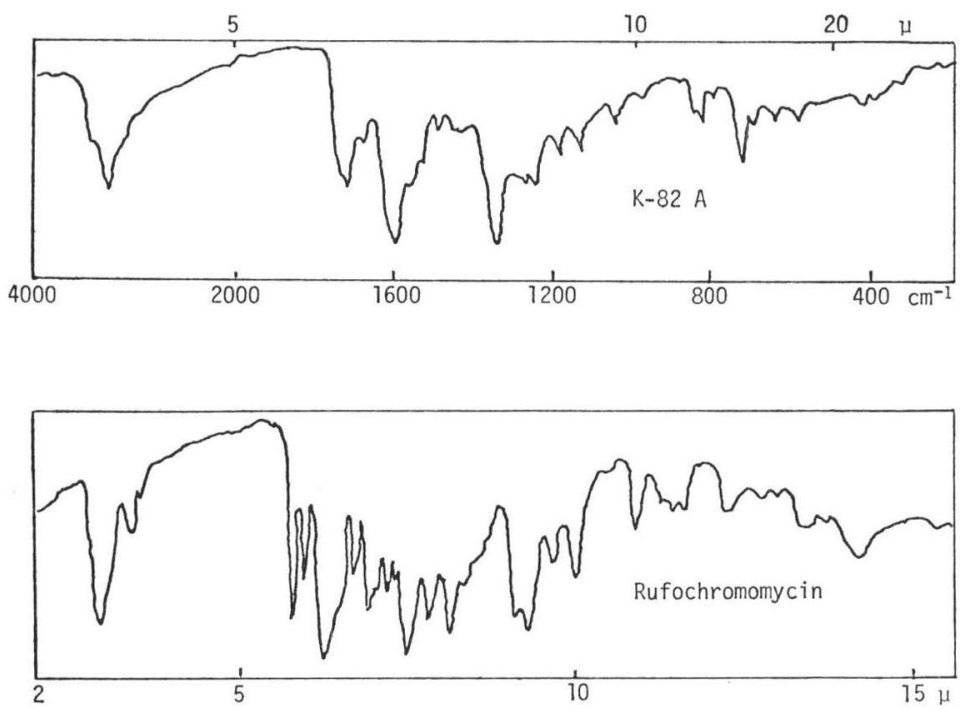

Fig. 4. Infrared absorption spectra of antibiotics $\mathrm{K}-82 \mathrm{~B}_{2}$ and $\mathrm{B}_{3}(\mathrm{KBr})$.

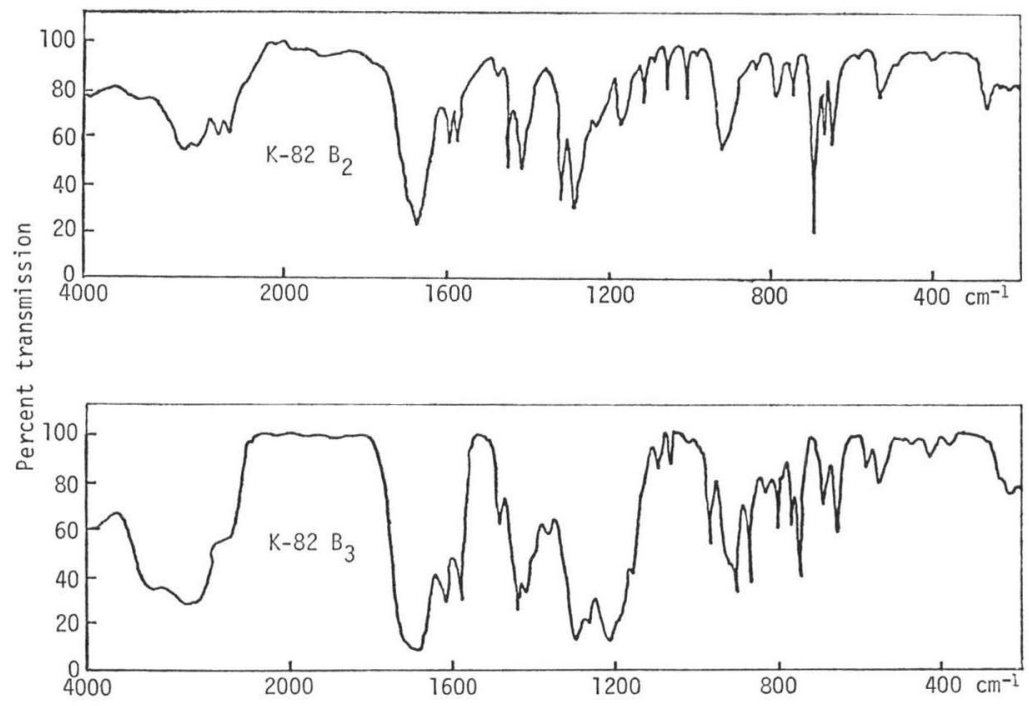

Table 2. Rf values of antibiotics $\mathrm{K}-82 \mathrm{~A}, \mathrm{~B}_{2}$ and $\mathbf{B}_{3}$.

\begin{tabular}{l|c|c|c}
\hline \multirow{2}{*}{ Solvent system } & \multicolumn{3}{|c}{$\mathrm{Rf}$} \\
\cline { 2 - 4 } & $\mathrm{A}$ & $\mathrm{B}_{2}$ & $\mathrm{~B}_{3}$ \\
\hline $\mathrm{CHCl}_{3}$-MeOH-AcOH $(20: 1: 1)$ & 0.34 & - & - \\
$\mathrm{AcOEt} \mathrm{BuOH}-\mathrm{AcOH}(10: 1: 1)$ & 0.48 & - & - \\
$\mathrm{C}_{6} \mathrm{H}_{6}$-AcOEt $(3: 1)$ & 0.00 & 0.43 & 0.21 \\
$\mathrm{C}_{6} \mathrm{H}_{6}$-AcOEt $(9: 1)$ & 0.00 & 0.30 & 0.05 \\
$\mathrm{C}_{6} \mathrm{H}_{6}$-AcOEt-MeOH $(30: 1: 1)$ & 0.00 & 0.66 & 0.41 \\
\hline
\end{tabular}

Biological Properties

(1) Antimicrobial activity

The antimicrobial spectra of $\mathrm{K}-82 \mathrm{~A}, \mathrm{~B}_{2}$ and $\mathrm{B}_{3}$ determined by dilution method on bouillon agar are shown in Table 3 . K-82 A was active against Gram-positive and Gram-negative bacteria and in particular, highly active against $B$. brevis and Sarcina lutea, whereas substance K-82 $\mathbf{B}_{2}$ and $\mathbf{B}_{3}$ showed only weak activities. 
Table 3. Antibacterial spectra of antibiotics K$82 \mathrm{~A}, \mathrm{~B}_{2}$ and $\mathrm{B}_{3}$.

\begin{tabular}{|c|c|c|c|}
\hline \multirow{2}{*}{ Test organism } & \multicolumn{3}{|c|}{$\mathrm{MIC}(\mathrm{mcg} / \mathrm{ml})$} \\
\hline & A & $\mathrm{B}_{2}$ & $\mathbf{B}_{3}$ \\
\hline Escherichia coli IFO 3301 & 2.0 & 500 & 500 \\
\hline Proteus vulgaris IFO 3167 & 2.0 & 500 & 500 \\
\hline $\begin{array}{c}\text { Pseudomonas aeruginosa } \\
\text { IFO } 3923\end{array}$ & 5.0 & 500 & 500 \\
\hline Bacillus brevis IFO 3331 & 0.2 & 250 & 250 \\
\hline Bacillus cereus IFO 3466 & 1.0 & 500 & 500 \\
\hline Bacillus subtilis PCI 219 & 0.5 & 500 & 500 \\
\hline Sarcina lutea $\quad$ IFO 3232 & 0.5 & 500 & 500 \\
\hline $\begin{array}{l}\text { Staphylococcus aureus } \\
\text { FDA } 209 \mathrm{P}\end{array}$ & 0.5 & 500 & 500 \\
\hline $\begin{array}{c}\text { Mycobacterium avium } \\
\text { IFO } 3082\end{array}$ & 2.0 & 500 & 500 \\
\hline
\end{tabular}

Table 4. Phage induction activities of K-82 A, bleomycin, mitomycin $\mathrm{C}$ and xanthomycin.

\begin{tabular}{|c|c|c|}
\hline & $\begin{array}{l}\text { Induction } \\
\text { activity } \\
\text { (unit/mg) }\end{array}$ & $\begin{array}{l}\text { Antibacterial } \\
\text { activity }\end{array}$ \\
\hline $\mathrm{K}-82 \mathrm{~A}$ & $2.0 \times 10^{6}$ & $\begin{array}{l}\operatorname{Gram}(+),(-) \\
\text { Mycobacteria }\end{array}$ \\
\hline Bleomycin & $3.5 \times 10^{5}$ & $\begin{array}{l}\text { Gram (+), (-) } \\
\text { Mycobacteria } \\
\text { Fungi }\end{array}$ \\
\hline Mitomycin & $1.0 \times 10^{7}$ & $\operatorname{Gram}(+),(-)$ \\
\hline Xanthomycin & $2.0 \times 10^{4}$ & $\begin{array}{l}\operatorname{Gram}(+),(-) \\
\text { Mycobacteria }\end{array}$ \\
\hline
\end{tabular}

(2) Phage induction activity

The phage induction activity was measured by phage induction-agar dilution method ${ }^{4)}$. The activity was expressed as the highest dilution for two times spontaneous phage count. K-82 A showed strong phage induction activity, that is, $2 \times 10^{8}$ units/mg but K-82 $B_{2}$ and $B_{3}$ showed no activity (Table 4).

\section{Comparison of Antibiotic K-82 A with Known Antibiotics}

From the nature, elementary analysis and antimicrobial activity of K-82 A, the antibiotic seemed to resemble rufochromomycin ${ }^{6)}$. K-82 A showed, however, absorption maxima $\left[\lambda_{\max }^{\mathrm{MeOH}} \mathrm{nm}\left(\mathrm{E}_{\mathrm{cem}}^{1 \%}\right)\right]$ at 230 (790), 250 (787.5), 280 (525) and 390 (306) in its ultraviolet absorption spectrum. Rufochromomycin showed absorption maxima at 247 (750) and 382 (322). Furthermore, K-82 A was differentiated from rufochromomycin by its infrared spectra as shown in Fig. 3. From these findings K-82 A is believed to be a new antibiotic.

\section{Acknowledgements}

We wish to thank Central Research Laboratories, Takeda Chemical Industries Co. Ltd. for the measurements of physicochemical properties.

\section{References}

1) Shirling, E. B. \& D. Gotrlieb: Method for chracterization of Streptomyces species. Inter. J. Syst. Bact. 16: $314 \sim 340,1966$

2) RAYNeR, R. W.: A mycological color chart. Commonwealth Mycological Inst., Kew, Surrey \& British Mycological Soc., 1970

3) Pridham, T.\& D. Gottlieb: The utilization of carbon compounds by some Actinomycetales as an aid of species determination. J. Bact. 56: 107 114, 1948

4) Shibata, M.; E. Higashide \& H. ONo: Unpublished.

5) Pridham, T. G. \& G. Tresner: Bergey's Manual of Determinative Bacteriology, 8th ed., p. 808, The Williams \& Wilkins Co., Baltimore, 1974

6) Mancy, D.; L. Ninet \& J. Preud-Homme: Brit. Patent 872,261, 1961 